\title{
CRM: A Conceptual Framework of Enablers and Perspectives
}

\author{
Saeed Gholami (Corresponding Author) \\ Graduate Research Student \\ Multimedia University, Malaysia \\ Tel: 60-13-698-7606 E-mail: gholami.mmu@gmail.com \\ Muhammad Sabbir Rahman \\ Lecturer in Marketing \\ Graduate School of Management (GSM) \\ Multimedia University, Malaysia \\ Tel: 60-19-239-4097Ｅ-mail: muhammad.sabbir@mmu.edu.my
}

$\begin{array}{lc}\text { Received: December 14, } 2011 & \text { Accepted: January 16, } 2012 \quad \text { Published: March 1, } 2012 \\ \text { doi:10.5430/bmr.v1n1p96 } & \text { URL: http://dx.doi.org/10.5430/bmr.v1n1p96 }\end{array}$

\begin{abstract}
The paper aims to consider the neglected perspective of customer relationship management (CRM) under the perspective of business performance. This research also identifies the key types of enablers in the relationship between CRM and business performance. Base on a broad literature review and utilizing from the Meta analysis, the paper identifies micro and macro analysis as two main forms of CRM perspectives as well as four main elements of enablers in the CRM area. The research has addressed new venue for scholars to test and examine the role of enablers in the CRM implementation as well as business performance. This study emphasized on dual value creation in the cycle of CRM perspectives, enablers and business performance. In addition, the manuscript demonstrates the possible conduct of CRM analysis and enablers on practical sample for companies.
\end{abstract}

Keywords: Customer relationship management (CRM), Enablers, Micro and macro perspectives, Business performance, Framework

\section{Introduction}

The term of Customer relationship management (CRM) has commonly been assumed to make a competitive edge for an organization, as well to have a positive impact on business performance. However, there is still much arguing over closely what constitutes CRM. In fact, many scholars have claimed that the precise meaning of CRM is not always clear in the text and literature(Nevin 1995; Parvatiyar and Sheth 2001).

According to the history of related researches, the CRM is a multi-dimensional construct consisting of four broad behavioral components: key customer focus, CRM organization, knowledge management, and technology-based CRM. Additionally,(Crosby and Johnson 2001; Ryals and Knox 2001; Day and Van den Bulte 2002; Kalustian, Lombardi et al. 2002; Sin, Tse et al. 2005; Daghfous and Barkhi 2009). and also, the successful CRM is addressing and predicated four major areas, including strategy, people, technology, and process(Fox and Stead 2001; Chen and Popovich 2003), and when these four elements work as whole can create a superior customer relation and business performance(Day 2003).

On the one hand, for practitioners, CRM states an enterprise approach to developing full-knowledge about customer behavior and preferences and to developing strategies and plans that persuade customers to continually increase their business relationship with the enterprise. On the other hand, Marketing scholars are considering the nature and scope of CRM and are developing conceptualizations regarding the dual value and process of collaborative and supportive relationships between customer and company (Parvatiyar and Sheth 2001).

The orbit of CRM extends into many fields of marketing and strategic decisions. CRM make reference to a conceptually extensive phenomenon of business activity, and if the phenomenon of cooperation and collaboration with customers becomes the dominant paradigm of marketing practice and research, CRM has the potential to emerge as the main perspective of marketing. From the corporate implementation point of view, CRM should not be misunderstood to 
simply mean a software solution implementation project. Building relationships with customers is a fundamental business of every enterprise, and it requires a holistic perspectives, enablers and strategy to make it successful(Parvatiyar and Sheth 2001).

The latest reports have highlighted 22 per cent of initiatives in CRM have a dissatisfactory outcome, 20 per cent of CRM initiatives harm the relationships of customer. And also, the researchers conclude that one in every three CRM deployments fails and fewer than 50 per cent of CRM assignments completely meet opportunities (Unit 2007; Frow, Payne et al. 2011). The main motivation of this study is to provide a conceptual framework for understanding both micro and macro perspectives and highlighting main enablers in CRM and new criteria in the business performance. A synthesis of existing perspectives in two broad micro and macro and most influencing enablers such as people, strategy, technology, and process to highlight the four new criteria- customer life time, referral, knowledge , and influencer valuefor measuring business performance.

The purpose of CRM is to improve marketing productivity. Marketing productivity is achieved by increasing marketing efficiency and by enhancing marketing effectiveness(Morgan, Clark et al. 2002; Sheth and Sisodia 2002). In CRM, marketing efficiency is achieved because cooperative and collaborative processes help in reducing transaction costs and overall development costs for the company. Two important processes of CRM include proactive customer business development and building partnering relationships with the most important customers(Parvatiyar and Sheth 2001).

Another motivation of this study is related to the stream of propositions based on conceptual framework elements that can help scholars to examine and test them as well as lead to the rapid development of CRM strategies, tools, and technologies. Likewise, specific enablers in the linkage between CRM and business performance that contribute to the fresh criteria in this area.

\section{Literature Review}

The study arranges the related parts that have direct relation with the motivation of study and research objectives as well reinforces the characteristics of main enablers. This section focuses on results of pervious researches and will synthesis all aspects of the main concepts of the study.

Nevin (1995) pointed up the term of CRM has become a buzzword, with the concept being used to reflect a number of contradictory enablers and perspectives in various areas and dissimilar levels such as theoretical, tactical, and strategic levels. For example, at a theoretical level, CRM can represent an emerging research paradigm in marketing(Parvatiyar and Sheth 2001). At a tactical level, CRM may mean database marketing(Chen and Popovich 2003) or electronic marketing (Mitussis, O'Malley et al. 2006). And finally, at a strategic level, CRM may imply customer retention or customer partnering(Vavra 1992; Peppers and Rogers 1993).

Consequently, a clarification and conceptualization of this construct is required to ensure that our knowledge of CRM grows in a "cumulative" method. In addition, while we observe that there has been an increase in the attention paid to CRM by practitioners and academics, to date no systematic attempt has been made to develop a valid measure of it, or to assess its influence on business performance through common perspectives and the major enablers (Nevin 1995; Sin, Tse et al. 2005). In this part of study, attempted highlight important parts that support related issues to the prepositions and conceptual framework.

\subsection{Customer Relationship Management}

CRM is a comprehensive strategy and process of acquiring, retaining, and partnering with selective customers to create superior dual value for both company and customer. It tracks the integration of marketing, customer service, sales, and the supply-chain roles of the organization to achieve superior efficiencies and effectiveness as two major dimensions of performance in delivering customer value(Parvatiyar and Sheth 2001). The processes of CRM have been mainly investigated by academicians and create a bundle of researches in this field (Kohli, Piontek et al. 2001; Parvatiyar and Sheth 2001; Day and Van den Bulte 2002; Leigh and Tanner Jr 2004; Zablah, Bellenger et al. 2004; Bueren, Schierholz et al. 2005; Richards and Jones 2008; Frow, Payne et al. 2011).

In these researches Seivastava and colleagues (1999) also Zablah and colleagues (2004) examined these processes into two chiefly levels as micro and macro, as well current studies emphasized them(Öztaysi, Sezgin et al. 2011). The micro level stress on management of customer interaction to maintain long period profitability and the macro level focuses on CRM as a companywide process(Day and Van den Bulte 2002; Payne and Frow 2005). In addition, Zablah and colleagues (2004) defined five perspectives for CRM that are, process, philosophy, strategy, technology, and capability.

As a result, measurement of CRM in the level of process emphasizes on the achievement and success CRM level related various processes and attempts to find an answer for important questions: how good are we doing in CRM process?" 
When analyzed from this point of view, the current CRM measurement process provides deficiency". Each of process levels needs specific analysis to understand the importance of both perspectives of process levels in the CRM arena.

\subsubsection{Micro perspective}

The micro process approach focuses on customer interaction management in order to maintain long term profitable customer relationships. (Srivastava, Shervani et al. 1999; Kohli, Piontek et al. 2001; Day and Van den Bulte 2002; Öztaysi, Sezgin et al. 2011). This approach covers managerial, human resource, technical, and economical aspects(Xu, Yen et al. 2002).Managerial aspect that should understand is CRM works when supported via corporate culture which cuddles customer-focused objectives. Without the comprehensive perception of customer-centered aims, the company will find it more difficult to actual leverage of the technology of cutting-edge. Personal aspect is vital part in the CRM. According to Krauss (2002), the hardest part of becoming CRM-oriented is not the technology, it is the people." Internal marketing, where human resources and marketing interface, instills in employees the greatest significance of service-mindedness and customer orientation. Four significant internal marketing processes include market training and education, internal communication, reward systems, and employee involvement(Sin, Tse et al. 2005).

Technical aspect is another element of micro perspective that focuses on this principal the quality of CRM efficient interactions of customer are not adequate any more. In order to topmost the return on these interactions, the company should deploy data warehousing and gain analytical applications of domain-specific, to create a sweeping customer perspective so that to successfully promote marketing activities. Two main feasible solutions in this part are SAS and JAVA because these tools helps companies obtain full view to identify, monitor, and response to the most profitable customer, as well as allow the users in the company working in various locations(Xu, Yen et al. 2002).

The finally aspect of micro analysis in the CRM is economical aspect. The competitive pressures will drive companies to automate the intra-company customer-facing process along back-office functions as supply chain functions. To reach competitive advantage, the company should map existing CRM efforts in marketing sales and service to support back-front functions, therefore, CRM is a long term investment approach, not a short-term one(Xu, Yen et al. 2002).

\subsubsection{Macro perspective}

The macro level process approaches CRM process as companywide process. Payne and Frow (2005) defined these processes as strategy development, value creation, channel integration, knowledge management and performance evaluation process (Kohli, Piontek et al. 2001; Day and Van den Bulte 2002; Öztaysi, Sezgin et al. 2011).the important analysis that require for the macro perspective include technology related, environment, and government and standards.

Technology related implies that Leading companies are using from e applications technologies to make a strong relationship with their customers. And IT solution in CRM combines the attaining of customer information from the company with the application of a series of technologies like data warehousing, OLAP, data mining, statistical analysis, and so forth for managing that information and converting it into business knowledge(Thearling, Berson et al. 2000; Chalmeta 2006)

The key to designing a CRM computer system is the intelligent integration of technological and functional components that allows a connection between the front office (sales, marketing and customer service) and back office (financial, logistics, warehousing, accounting, human resources, and so forth) systems. Customer contact management through any channel should enable a large quantity of information to be obtained and allow it to flow through the system with its own logical organization, thus making it easier to apply data analysis tools(Krauss 2002; Chalmeta 2006).

In the other word, technology plays an important role in CRM in adding to firm intelligence(Boyle 2004). the startling advances in IT prepare companies with the ability to gather, store, analyze, and share customer information in ways that significantly promote their ability to react to the needs and wants of individual customers and thus to attract and maintain customers(Butler 2000). The promise of one-to-one relationships, customer-value analysis, and mass customization(Hart 1995) are now brought to reality by extraordinary advances in IT, transforming the traditional perspective to CRM to an integrated, web-enabled approach, featured by tools like customer IS, automation of customer support processes, and call centers(Ghodeswar 2001). CRM calls for "information-intensive strategies" that use computer technologies in making relationships, leveraging existing technology and linking technology deployment to targeted business initiatives (Sin, Tse et al. 2005).

Environment is next factor of macro analysis in the CRM field. In today's business environment, most companies interface with their customers via a variety of channels including service personnel, call centers, sales people, marketing section, Internet websites, fulfillment houses, development agent of market and business, as well cross-functional teams for large customers(Parvatiyar and Sheth 2001). 
Additionally, the CRM environment prepares an efficient setting to analyze the relationship among various measures. Therefore, Gustafsson, Johnson, and Roos (2005) investigate the distinctiveness of constructs that tap satisfaction, emotional and calculative commitment as they are associated to retention. This work stresses the issue that though constructs relevant to CRM may be conceptually distinct, their effects may be empirically indistinguishable, as is found with the satisfaction and affective commitment constructs. This finding suggests that careful attention to measurement issues is required when testing subtle theoretical effects relevant to the CRM domain(Parvatiyar and Sheth 2001).

Government and Standard focuses on a plenty of legal and standard issues in CRM, particular e-CRM. Creates friendly standard pertaining environment for open communication, encouraging front and back office people, and monitor changes in CRM system and review causal factors can be critical parameter in CRM.

As a result, CRM relates to strategy, the management of the dual creation of value, the intelligent use of data and technology, the acquisition of customer knowledge and the diffusion of this knowledge to the appropriate stakeholders, the development of appropriate (long-term) relationships with specific customers and/or customer groups, and the integration of processes across the many areas of the firm and across the network of firms that collaborate to generate customer value(Boulding, Staelin et al. 2005; Öztaysi, Sezgin et al. 2011). According to the above discussion, the paper offers the following proposition:

\section{P1: the CRM issues cover two main macro and micro perspectives in the flat market era.}

\subsection{Enablers}

Strategy, people, technology, and processes are all vitally important to CRM, but it is the individual employees who are the building blocks of customer relationships(Brown 2000; Sin, Tse et al. 2005). the CRM solutions platform needs to be based on interactive technology and processes, people, and strategy(Parvatiyar and Sheth 2001). It should assist the company in developing and enhancing customer interactions and one-to-one marketing through the application of suitable intelligent agents that help develop the front-line relationship with customers. Such a system would identify appropriate data inputs at each customer interaction site and use analytical platforms to generate appropriate knowledge output for front-line staff during customer interactions (Parvatiyar and Sheth 2001; Chang, Park et al. 2010).

People is the first enablers in the CRM and business performance loop as well it is the biggest challenge has always been recruiting the right people and training them in the company's business rules and standards in order to achieve consistency. The HR plays a key role in ensuring that constant retooling and retraining takes place in the operation to meet ever-evolving challenges. Life-long learning should be an integral part of any business, to enable it to respond to its rivals' activities with fresh initiatives within the company(Merkel, Jackson et al. 2010).

HRM has to be aligned with the business strategy of the company, to work in keeping with all of its corporate objectives, and to be prepared not only to help in implementing all changes necessary but also to instigate and be at the vanguard of change programs. Further, HRM should be aware of employee interests within the organization yet conscious of its place as the "power house" when controversial business decisions, such as downsizing, have to be implemented(Merkel, Jackson et al. 2010). And aslo changing the company culture, the CRM project requires a restructuring of the company's job manual and organizational diagram, as "customer teams" made up of staff from different departments, like marketing, design, sales, and so forth, will be created. It is a less hierarchical means of organization similar to management by processes (Chalmeta 2006).

TECHNOLOGY, Scholars from other academic disciplines, particularly those interested in the area of information systems and decision technologies, are also exploring new methodologies and techniques that create efficient frontline information systems (FIS) to effectively manage relationships with customers(Parvatiyar and Sheth 2001). Several software tools and technologies claiming solutions for various aspects of CRM have recently been introduced for commercial application. The majority of these tools promise to individualize and personalize relationships with customers by providing vital information at every point in the interface with the customer. Techniques such as collaborative filtering, rule-based expert systems, artificial intelligence, and relational databases are increasingly being applied to develop enterprise level solutions for managing information on customer interactions(Parvatiyar and Sheth 2001; Boulding, Staelin et al. 2005).

While CRM is driven by technology, it's not about technology. The point of CRM is to improve your customer-facing business processes; technology is only a means to achieving that end. Every successful implementation begins by recognizing this fact - and by creating operational structures that reinforce it(Boulding, Staelin et al. 2005). Strategy, is regarding new edges in the market while slowing the erosion of present advantages (Day and Wensley 1988). And also, CRM is a strategic business not only focuses on a technology solutions as most often accepted in practices(Osarenkhoe and Bennani 2007). 
Process, common understanding of CRM Processes in customer oriented viewpoint a measurement tool which addresses seven key processes that are; targeting management, customer information management, production and service customization, expansion management, referrals management, termination management and win back(Parvatiyar and Sheth 2001). The five key strategic processes of CRM, proposed by Payne and Frow (2005) are used as a structure to consider how various dark side behaviors can be addressed. At the centre of these processes, more enlightened CRM strategy is revealed to expand from addressing the ongoing cross-functional processes of: value creation, strategy development, multi-channel integration and customer experience, information management, and, performance assessment (Frow, Payne et al. 2011) .

Therefore, proper monitoring processes are needed to safeguard against failure and manage conflicts in relationships. Monitoring processes include periodic evaluation of goals and results, initiating changes in the relationship structure, design, or the governance process if needed, and creating a system for discussing problems and resolving conflicts. Good monitoring procedures help avoid relationship destabilization and the creation of power asymmetries. They also help keep CRM programs on track given proper alignment of goals, results, and resources (Parvatiyar and Sheth 2001).hence, the paper suggest the second proposition:

\section{P2: Four main enablers in the CRM and business performance are people, technology, strategy, and process.}

P3: Four main enablers that play major role in business performance are people, technology, strategy, and process.

The thought that dual creation of value is at the heart of CRM is moreover evident in all previous studies that examine the company-customer boundary. For example, Cao and Gruca (2005) offer a framework whereby the company is able to better limit its target market to consumers who both want to hear about the company's particular present and qualify for that offer. The company does not dispatch messages to customers who are improbable to react thus minimizing the disturbance to these customers. Equally, the company does not send messages to customers who are unlikely to qualify for the offer, thus minimizing their dissatisfaction. The authors note that this leads to an obvious win-win situation for the company and its customers (Boulding, Staelin et al. 2005; Cao and Gruca 2005).

In contrast, one study develops a pricing plan which creates a differential value suggestion for different marketplace segments. This research remarks that this raises the issue of fairness and trust because the objective is for the company to use knowledge about customers to extract more value for the company and thus make less value for the customer(Lewis 2005). In the same way, Ryals (2005) shows that companies decrease their attention to customers after they decide which they are not able to earn sufficient value from these customers. Therefore, for definite customers, value is taken away so that company can enhance the value they obtain. In a similar manner, some researches examine the dual creation of value from the company view. They recommend a process that enables companies to transfer customers into more profitable channels (Boulding, Staelin et al. 2005; Ryals 2005; Thomas and Sullivan 2005).hence, the paper offers the third proposition as follow:

\section{P4: The core element from interaction of CRM, enablers, and business performance is dual value creation}

Measuring performance is as an old story in the world business. There is some framework such as the quantum performance management model, performance prism, and balanced scorecard that BSC covers financial and nonfinancial aspects in business organizations(Kaydos 1991). Developing performance metrics is always a challenging activity as most firms are inclined to use existing marketing measures to evaluate CRM(Parvatiyar and Sheth 2001).For measuring CRM performance, a balanced scorecard that combines a variety of measures based on the defined purpose of each program (or each cooperative/collaborative relationship) is recommended(Kaplan and Norton 1992). In other words, the performance evaluation metrics for each relationship or CRM program should mirror the set of defined objectives for the program. However, certain global measures of the impact of a CRM effort by a company are also possible(Parvatiyar and Sheth 2001).

Reliable and valid scale was developed to measure the four dimensions of CRM: key customer focus (CLV), CRM organization, knowledge management and technology-based (CKV) CRM (business outcomes-framework)(Sin, Tse et al. 2005).. Furthermore, Thomas and Sullivan (2005) show that an enterprise CRM system that coordinates and integrates data from different channel sources enables the firm to gain new knowledge about each customer and thus enhance business performance.

The major theoretical and practical research question posed by these new forms of data is how can they be tapped in to and utilized for CRM purposes(Hennig-Thurau, Malthouse et al. 2010)? Some proposed metrics are the aforementioned CLV, but also customer referral value (CRV) which involves determining how much of each customer's value stems from his or her referrals of new customers, customer influencer value (CIV) which is more subtle that referring but involves influencing through information-sharing, and customer knowledge value (CKV) which involves indentifying 
those customers with the best knowledge of the marketplace to help the company. According to the knowledge-based view of the firm, the primary rationale for a firm's existence is the creation, transfer, and application of knowledge. From a CRM perspective, knowledge can be understood as what has been learned from experience or empirical study of consumer data. Key facets of "knowledge management" include knowledge learning and generation, knowledge dissemination and sharing, and knowledge responsiveness (CKV) (Kumar, Aksoy et al. 2010; Harrigan 2011).

Customer lifetime value is defined as "the net of the revenues obtained from that customer over the lifetime of transactions with that customer minus the cost of attracting, selling, and servicing that customer, taking into account the time value of money"(Jain and Singh 2002). In CRM, marketers assess the lifetime value of each customer individually to decide whether to build a relationship with him/her and provide customized offerings. This decision should enhance company profit by focusing on profitable customers via more(Sin, Tse et al. 2005; Harrigan 2011). (Sin, Tse et al. 2005; Kumar, Aksoy et al. 2010; Harrigan 2011). The fourth preposition is:

\section{P5: Business performance can measure through $\mathrm{CLV}, \mathrm{CR} V, \mathrm{CV}$, and $\mathrm{KV}$ in order to reduce the long-term failure.}

This study focuses on the results of previous researches to depict conceptual framework that it is comprised of three major parts, including CRM perspectives, enablers, and business performance. The first part of the framework is CRM perspectives that concentrate on the micro and macro analysis. The micro analysis can measure via managerial, personal (HR), technical and economical aspects as well macro analysis utilize technology related, environment, and standard. These analyses form the first group of independent variables.

Enablers are the second group of independent variables that consist of four chief dimensions namely people, process, strategy, and technology. Given to discussion and performed synthesis in the literature review these enablers affect on CRM analysis and business performance. Hence, those need the different statistical methods to examine and analysis.

The third part of conceptual framework is business performance that measures through customer lifetime value (CLV), customer referral value (CRV), customer influencer value (CIV), and customer knowledge value (CKV) as four main dimensions group of dependent variables. The researcher and decision makers can present a comprehensive judgment regarding the long term relationship in the loop of CRM perspectives, enablers and its business performance.

\section{Methodology}

The study utilized Meta analysis as main methodology. The Meta -analysis focuses on analysis of analyses, refer to the collecting of outcome from individual researches for the purpose of integrating the finding, as well as the modern version of secondary researches (Glass 1976). So far the most usual use of the meta-analysis has been in the literature review of quantitative researches that help the general strength of the effect under different circumstances. In recent time, meta-analysis techniques has become more common in the researches (DeCoster 2009). Hence, this study focuses on the results of previous researches to depict conceptual framework that it is comprised of micro and macro perspectives of CRM, enablers, and business performance.

\section{Discussion and Conclusion}

The customer relationship management process is a continuous learning process where implies the relevant information is transformed in the relationship of company and its customer groups. The focal point for thinking concerning the influence of CRM activities on the business performance of the company was originally extracted from competitive advantage model that developed by Day and Wensley (1988). In view point of enablers, CRM is a combination of people; strategy, technology, and process that search for understand a company customer. Indeed, it is a comprehensive approach to managing relationship through customer retention and development of relationship, as well as CRM has expand from advances in IT and organizational changes in the processes of customer-centric. Therefore, the balanced and integrated approach to four main enablers is requiring for managing a successful implementation of CRM).

In view point of CRM, the CRM is an enterprise-wide approach that focuses on customer-centric model that should be set up around the customer. Hence, it is a collection of micro and macro analysis as continuous effort that needs reshaping core business processes starting from customer side and connecting customer feedback. Consequently, CRM covers managerial, personal, technical, and economical aspects in the micro analysis, as $\mathrm{w}$ ell as government/standards, environment, and technology related aspects as macro analysis in order to the finally outcome that lead to the dual value creation in the cycle of CRM perspectives, enablers, and business performance.

The research has addressed new venue for scholars to test and examine the role of enablers in the CRM implementation as well as business performance with fresh criteria such as CLV, CRV, CIV, and CKV because these metrics create new forms of data for CRM purpose. And also, the study can utilize for rank of enablers and dimensions of micro and macro 
analysis in business performance to achieve a strategic roadmap and set up preventive actions rather than corrective actions in the CRM approach. These actions can help decision makers to gain efficient performance.

This manuscript can change the practitioners view from product-focus to customer-focus, make long-term relationship, and create dual value for all shareholders. Using cluster analysis from both micro and macro analysis and enablers to discover new customer insight and improve customer retention via preventive action and predictive modeling is another implication of the study. To sum up, these analyses establish customer database to benchmark customer satisfaction through mentioned metrics and learn from successes and failures to help future improvements.

There are two major streams in the CRM literature. The first one is cultural stream that describes market orientation as a culture which pledge the company to the continuous creation dual value for company and its customers. The behavioral stream is the next stream of study that represents market orientation in terms of definite behaviors related to the company-wide creation of market intelligence. Hence, the future study can be designed the empirical research on the impact of CRM on business performance in both cultural and behavioral perspectives as well as the rank of their criteria to comparing each of them.

The six mutually dependent criteria highlighted for CRM in the previous researches, including emphasis on quality, manage customer service, invest in people, keeping dialogue with customers, gaol setting and evaluating performance, and relationship-based interfaces (Donaldson and O'Toole 2007). And also the core dimensions of relationship strategy implementation have summarized in $5 \mathrm{~S}$ term that content of structure, staff, system, schemes(Osarenkhoe and Bennani 2007). To use effective of mutual criteria and $5 \mathrm{~S}$ dimensions in the marketing literature, the next future study can focus on them.

Future research could also include case studies in order to achieve best practice can help micro and macro, as well as enablers in creating dual value in the companies because the case study highlights the similarities and differences between both theory and practice of implementation effective customer relationship management strategies. And finally future research can focus on the role and justification of common barriers and obstacles in this area as well as the assessment of critical risk factors related to these barriers. Specially, management commitment and support, change management, organizational structure, IT, and CRM projects.

\section{References}

Ahmed, M., Ahmed, Z., Ahmed, I. \& Nawaz, M. (2009). Comparative Significance of the Four Perspectives of Balanced Scorecard.

Boulding, W., Staelin, R., Ehret, M. \& Johnston, W. J. (2005). A customer relationship management roadmap: What is known, potential pitfalls, and where to go. The Journal of Marketing, 69:4, 155-66. http://dx.doi.org/10.1509/jmkg.2005.69.4.155

Boyle, M. J. (2004). Using CRM software effectively. The CPA Journal, 74:7.

Brown, S. A. (2000). Customer relationship management: A strategic imperative in the world of e-business. J. Wiley \& Sons Canada.

Bueren, A., Schierholz, R., Kolbe, L. M. \& Brenner, W. (2005). Improving performance of customer-processes with knowledge management. Business Process Management Journal, 11:5, 573-88. http://dx.doi.org/10.1108/14637150510619894

Butler, S. (2000). Customer Relationships: Changing the Game: CRM in the e-World. Journal of Business Strategy, 21:2, 13-14. http://dx.doi.org/10.1108/eb040067

Cao, Y. \& Gruca, T. S. (2005). Reducing adverse selection through customer relationship management. Journal of Marketing, 69:4, 219-29. http://dx.doi.org/10.1509/jmkg.2005.69.4.219

Chalmeta, R. (2006). Methodology for customer relationship management. Journal of Systems and Software, 79:7, 1015-24. http://dx.doi.org/10.1016/j.jss.2005.10.018

Chang, W., Park, J. E. \& Chaiy, S. (2010). How does CRM technology transform into organizational performance? A mediating role of marketing capability. Journal of Business Research, 63:8, 849-55. http://dx.doi.org/10.1016/j.jbusres.2009.07.003

Chen, I. J. \& Popovich, K. (2003). Understanding customer relationship management (CRM): People, process and technology. Business Process Management Journal, 9:5, 672-88. http://dx.doi.org/10.1108/14637150310496758

Crosby, L. A. \& Johnson, S. L. (2001). High performance marketing in the CRM era. Marketing Management, 10:3, $10-11$. 
Daghfous, A. \& Barkhi, R. (2009). The strategic management of information technology in UAE hotels: An exploratory study of TQM, SCM, and CRM implementations. Technovation, 29:9, 588-95. http://dx.doi.org/10.1016/j.technovation.2009.05.007

Day, G. S. (2003). Creating a superior customer-relating capability. MIT Sloan Management Review, 44:3, 77-82.

Day, G. S. \& Van den Bulte, C. (2002). Superiority in customer relationship management: Consequences for competitive advantage and performance. Marketing Science Institute.

Day, G. S. \& Wensley, R. (1988). Assessing advantage: a framework for diagnosing competitive superiority. The Journal of Marketing, 1-20. http://dx.doi.org/10.2307/1251261

DeCoster, J. (2009). Meta-analysis notes.

Donaldson, B. \& O'Toole, T. (2007). Strategic market relationships: from strategy to implementation. John Wiley \& Sons Inc.

Fox, T. \& Stead, S. (2001). Customer relationship management: Delivering the benefits. White Paper of Secor Consulting.

Frow, P., Payne, A., Wilkinson, I. F. \& Young, L. (2011). Customer management and CRM: addressing the dark side. Journal of Services Marketing, 25:2, 79-89. http://dx.doi.org/10.1108/08876041111119804

Ghodeswar, B. (2001). Winning markets through effective customer relationship management. Customer relationship management: emerging concepts, tools, and applications, 71.

Glass, G. V. (1976). Primary, secondary, and meta-analysis of research. Educational researcher, 5:10, 3-8.

Harrigan, P. (2011). Modelling CRM in the social media age.

Hart, C. W. L. (1995). Mass customization: conceptual underpinnings, opportunities and limits. International Journal of Service Industry Management, 6:2, 36-45. http://dx.doi.org/10.1108/09564239510084932

Hennig-Thurau, T., Malthouse, E. C., Friege, C., Gensler, S., Lobschat, L., Rangaswamy, A. \& Skiera, B. (2010). The impact of new media on customer relationships. Journal of Service Research, 13:3, 311.

Jain, D. \& Singh, S. S. (2002). Customer lifetime value research in marketing: A review and future directions. Journal of interactive Marketing, 16:2, 34-46. http://dx.doi.org/10.1002/dir.10032

Kalustian, J., Lombardi, B. \& Fletcher, W. (2002). CRM checklist for success. Pharmaceutical Executive, 22:2, 64-67.

Kaplan, R. S. \& Norton, D. P. (1992). The balanced scorecard-measures that drive performance. Harvard Business Review, 70:1, 71-79.

Kaydos, W. (1991). Measuring, managing, and maximizing performance. Productivity Press.

Kohli, R., Piontek, F., Ellington, T., VanOsdol, T., Shepard, M. \& Brazel, G. (2001). Managing customer relationships through E-business decision support applications: a case of hospital-physician collaboration. Decision Support Systems, 32:2, 171-87. http://dx.doi.org/10.1016/S0167-9236(01)00109-9

Krauss, M. (2002). AT MANY FIRMS, TECHNOLOGY OBSCURES CRM. Marketing, 36:6, 5.

Kumar, V., Aksoy, L., Donkers, B., Venkatesan, R., Wiesel, T. \& Tillmanns, S. (2010). Undervalued or Overvalued Customers: Capturing Total Customer Engagement Value. Journal of Service Research, 13:3, 297.

Leigh, T. W. \& Tanner Jr, J. F. (2004). Introduction: JPSSM special issue on customer relationship management. Journal of Personal Selling and Sales Management, 24:4, 259-62.

Lewis, M. (2005). Incorporating strategic consumer behavior into customer valuation. Journal of Marketing, 69:4, 230-38. http://dx.doi.org/10.1509/jmkg.2005.69.4.230

Merkel, J., Jackson, P. \& Pick, D. (2010). New challenges in retail human resource management. Retailing in the 21st Century, 257-70.

Mitussis, D., O'Malley, L. \& Patterson, M. (2006). Mapping the re-engagement of CRM with relationship marketing. European Journal of Marketing, 40:5/6, 572-89. http://dx.doi.org/10.1108/03090560610657840

Morgan, N. A., Clark, B. H. \& Gooner, R. (2002). Marketing productivity, marketing audits, and systems for marketing performance assessment: integrating multiple perspectives. Journal of Business Research, 55:5, 363-75. http://dx.doi.org/10.1016/S0148-2963(00)00162-4 
Nevin, J. R. (1995). Relationship marketing and distribution channels: exploring fundamental issues. Journal of the Academy of Marketing Science, 23:4, 327-34. http://dx.doi.org/10.1177/009207039502300413

Osarenkhoe, A. \& Bennani, A. E. (2007). An exploratory study of implementation of customer relationship management strategy.' Business Process Management Journal, 13:1, 139-64. http://dx.doi.org/10.1108/14637150710721177

Öztaysi, B., Sezgin, S. \& Özok, A. F. (2011). A Measurement Tool for Customer Relationship Management Processes. Industrial Management \& Data Systems, 111:6, 7-7.

Parvatiyar, A. \& Sheth, J. N. (2001a). Conceptual framework of customer relationship management. New Delhi, India: Tata/McGraw-Hill.

Parvatiyar, A. \& Sheth, J. N. (2001b). Customer relationship management: emerging practice, process, and discipline. Journal of Economic and Social Research, 3:2, 1-34.

Payne, A. \& Frow, P. (2005). A strategic framework for customer relationship management. Journal of Marketing, 69:4, 167-76. http://dx.doi.org/10.1509/jmkg.2005.69.4.167

Peppers, D. \& Rogers, M. (1993). The one to one future: Building relationships one customer at a time. Currency Doubleday New York.

Richards, K. A. \& Jones, E. (2008). Customer relationship management: Finding value drivers. Industrial Marketing Management, 37:2, 120-30. http://dx.doi.org/10.1016/j.indmarman.2006.08.005

Ryals, L. (2005). Making customer relationship management work: The measurement and profitable management of customer relationships. Journal of Marketing, 69:4, 252-61. http://dx.doi.org/10.1509/jmkg.2005.69.4.252

Ryals, L. \& Knox, S. (2001). Cross-functional issues in the implementation of relationship marketing through customer relationship management. European Management Journal, 19:5, 534-42. http://dx.doi.org/10.1016/S0263-2373(01)00067-6

Sheth, J. N. \& Sisodia, R. S. (2002). Marketing productivity: issues and analysis. Journal of Business Research, 55:5, 349-62. http://dx.doi.org/10.1016/S0148-2963(00)00164-8

Sin, L. Y. M., Tse, A. C. B. \& Yim, F. H. K. (2005). CRM: conceptualization and scale development. European Journal of Marketing, 39:11/12, 1264-90. http://dx.doi.org/10.1108/03090560510623253

Srivastava, R. K., Shervani, T. A. \& Fahey, L. (1999). Marketing, business processes, and shareholder value: an organizationally embedded view of marketing activities and the discipline of marketing. The Journal of Marketing, 63, 168-79. http://dx.doi.org/10.2307/1252110

Thearling, K., Berson, A. \& Smith, S. (2000). Building data mining applications for CRM. New York et al.

Thomas, J. S. \& Sullivan, U. Y. (2005). Managing marketing communications with multichannel customers. Journal of Marketing, 239-51. http://dx.doi.org/10.1509/jmkg.2005.69.4.239

Unit, E. I. (2007). Collaboration: Transforming the way business works. A report from the EIU sponsored by Cisco Systems.

Vavra, T. G. (1992). Aftermarketing: How to keep customers for life through relationship marketing. Irwin.

Xu, Y., Yen, D. C., Lin, B. \& Chou, D. C. (2002). Adopting customer relationship management technology. Industrial Management \& Data Systems, 102:8, 442-52. http://dx.doi.org/10.1108/02635570210445871

Zablah, A. R., Bellenger, D. N. \& Johnston, W. J. (2004). An evaluation of divergent perspectives on customer relationship management: Towards a common understanding of an emerging phenomenon. Industrial Marketing Management, 33:6, 475-89. http://dx.doi.org/10.1016/j.indmarman.2004.01.006 


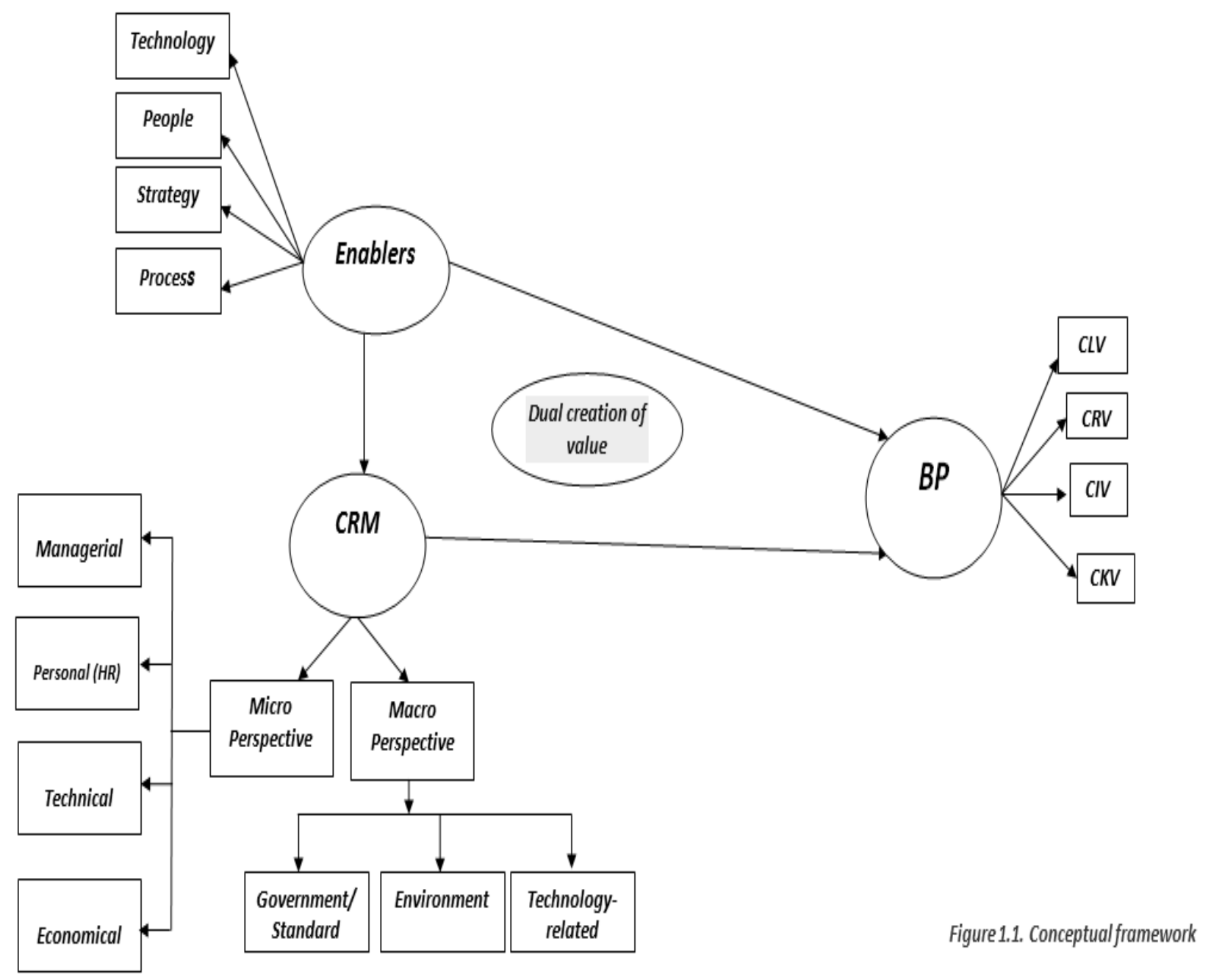

Figure 1.1 Conceptual framework 